How to cite this article:

Bala, H., Amran, N. A., \& Shaari, H. (2018). Audit committee attributes and auditor brand name of listed companies in Nigeria. International Journal of Management Studies, 25(2), 39-70.

\title{
AUDIT COMMITTEE ATTRIBUTES AND AUDITOR BRAND NAME OF LISTED COMPANIES IN NIGERIA
}

\author{
HUSSAINI BALA \\ Department of Accounting, Kaduna State University, Nigeria \\ NOOR AFZA AMRAN \\ HASNAH SHAARI \\ Tunku Puteri Intan Safinaz School of Accountancy \\ Universiti Utara Malaysia \\ *Corresponding Author: hussainumi2013@gmail.com
}

\begin{abstract}
This paper examines the effect of audit committee attributes on auditor brand name proxy by the Big 4. The study utilizes 88 listed firms in Nigeria through 440 firm-year observations ranging between the years 2012 to 2016. The data for the study were extracted from the firms' annual reports and Thompson Reuters Data Stream. A panel logistic regression was employed to estimate the model of the study. Consistent with complementary hypothesis the findings demonstrate that audit committee attributes (audit committee independence, audit committee financial accounting experts, audit committee legal expert, female audit committee member and audit committee stock ownership) are positively related to auditor brand name. The findings also support the substitution hypothesis perspectives by revealing an inverse relationship between audit committee meetings, audit committee tenure, audit committee chair and auditor brand name. Our findings offer an initial insight on the effect of audit committee legal expert, and audit committee stock ownership on auditor brand name. Thus, the findings can benefit existing and prospective shareholders who are the direct users of financial reports. This study can also help policy-makers and regulators by allowing them to better recognize the importance of these distinctive audit committee attributes in enhancing the quality of audits, which is one of the most vital elements of improving financial reporting quality.
\end{abstract}


IJMS 25 (2), 39-70 (2018)

Keywords: Audit committee, Audit quality, Audit size, Gender diversity, Ownership.

Received: 19/07/2018 Revised: 25/07/2018 Accepted: 23/05/2019 Published: 15/12/2019

\section{Introduction}

Auditing is a systematized and autonomous examination of accounts of an organization to ascertain the truth and fairness of the financial reports. Thus, auditing is expected to play a monitoring role by minimizing agency costs between management and corporates' stakeholders. Invariably auditors are assumed to act in investors' interests and aid financial statement users by confirming the reliability of financial reporting. This is because high-quality information is likely to lessen asymmetric information problems between the firm and its investors, and accordingly, cut the agency costs (Bushman \& Smith, 2001).

Consequently, it is argued that an active audit committee demands for a higher external audit effort to protect firms' reputation, endorse shareholders' interest and reinforce the integrity of financial reporting (Carcello, Hermanson, Neal \& Riley, 2002; Huang, 2006). The foregoing argument supports the complementary hypothesis of audit which presumes that external auditors play a pivotal role in corporate governance which functions as a complementary instrument for improving the legal protection of outside stakeholders (Huang, 2006; Choi \& Wang, 2003). As a result, this reduces agency complicit between firm's insiders and external stakeholders. This is because the external stakeholders rely heavily on external auditors' monitoring efforts (Ball, Kothari, Robin, \& Pope, 2000). The substitution hypothesis proposes that for some firms to have a high quality external auditing to serve as a substitute for legal protection, and to lessen agency conflicts between firms' internal and external stakeholders in a weak legal environment (Choi \& Wang ,2003). Hence, such firms in a weak legal environment will have a higher demand for better audits than companies in strong legal environment (Gomes, 2000; Klapper \& Love, 2004). In contrast, an inverse association between governance mechanisms and audit quality might be expected if good governance can substitute for external auditing, leading to a decline in audit 
fees (Hay, Knechel, \& Wong, 2006). From the above argument, it is expected that an effective audit committee will demand for greater level of assurance. This is likely by engaging Big 4 auditors to provide higher quality of auditing services which in turn improve the financial reporting quality.

Therefore, despite the foregoing arguments, the regulatory authorities and investors frequently interrogate the job of both audit committee and external auditors since the audited financial reports have been exposed to be fraudulent in many of the contemporary financial scandals such as Enron and WorldCom. Consequently, since the audit committee selects the external auditor while the external auditor reports to the audit committee, there is a likelihood that both the two monitoring devices may operate jointly to limit accounting manipulation and enhance financial reporting quality (Alves, 2013).

In light of the foregoing, this study is set to examine the influence of audit committee attributes in the selection of auditor brand name of listed companies in Nigeria. Thus the study is inspired by the recent instantaneous increase and dominance of Big 4 auditors in the Nigerian audit market, which directly affects the fees that is paid to the external auditors by their clients. Consequently, Nairametrics (2017) gathered that the Big 4 auditors earned about 6.4 billion Naira (equivalent to 20.3 million USD) in the auditing services of the 28 largest firms in Nigeria in 2016. However, the question of whether Big 4 auditors offer higher financial reporting quality than the nonBig 4 auditors has continued to be a debatable issue (Jiang, Wang, \& Wang, 2018).

\section{Literature Review and Hypothesis Development}

Audit committee plays a vital role in corporate governance practices by overseeing the quality of audits. Thus, an active audit committee that has pertinent expertise and which is independent of management, is presumed to enhance approaches to audits which enriches audit quality and in return increases financial reporting quality (Cohen, Krishnamoorthy \& Wright, 2002; DeFond \& Zhang, 2014; Sulaiman, 2017). For that, better auditing is vital for the steadfastness of the financial reports since it is assumed to safeguard the interest of the 
investors and other stakeholders (Sulaiman, 2017). Prior studies on audit quality have argued that audit firm size denoted by Big 4 auditors is a strong surrogate for audit quality since larger auditors are expected to have strong enthusiasms and are more proficient to provide high quality audits (DeAngelo, 1981; DeFond \& Zhang, 2014). Studies that have been conducted on the connection between audit committee and audit firm size support the complementary relationship between audit committee attributes and audit firm size (Akhalumeh, Agweda, \& Ogunkuade, 2017; Ejeagbasi, Nweze, Ezeh, \& Nze, 2015; Jiraporn, Chintrakarn, Tong, \& Treepongkaruna, 2018). This suggests that an active audit committee purchases a high quality audit in their demand for greater assurance. The above findings have been validated by the research conducted by Zhang, Zhou and Zhou (2007) who explore the influence of audit committee and audit independence. They demonstrate that effective audit committee enhances audit quality by engaging the Big 4 auditors.

\section{Agency Theory}

The agency theory posits that monitoring devices align the interests of the management with the interests of owners in order to lessen the conflict of interest as well as any likely managers' opportunistic behaviours that could arise (Jensen \& Meckling, 1976). Consequently, the management might be more focused in their own interests over the stockholders' interests of wealth maximizing which increases agency cost. Yet, agency cost arises because of the dissimilarities between ownership and the control from management leading to information asymmetry between the managers and the stockholders. Therefore, it has been affirmed that agency cost intensifies the demand for monitoring devices that will provide assurance of the managers' performance in harmony with the contract (Huang, 2006). Several governance mechanisms can be applied in aligning the interests of the stockholders and managers. These comprise internal mechanisms such as boards of directors, audit committee, and external mechanisms like the external auditors (Fama \& Jensen, 1983). Therefore, a seamless combination of mechanisms which are being used, can be considered as a composite where the effectiveness of one device depends on the effectiveness of the other (Davis \& Useem, 2002). As such, it is expected when the audit committee engages better auditors, that can curtail the opportunistic reporting by manager and thus enhance financial reporting quality (Defond \& Jiambalvo, 1991). 


\section{Institutional Theory}

Institutional theory supports how governance devices achieve formal roles that help to legitimise the communication amid the key players within the corporate governance. With reference to the institutional theory, the audit committee members will act to affirm to other institutions and that audit committees over time, will tend to become like the others within the similar industry. The audit committee members may have had similiar experiences as well as the management. Thus the audit committees and the boards will fulfill an imperative signaling role to those outside the institution such as existing or potential shareholders by deliberating perceptions of reliance and proficiency in the workings of the audit committee (Cohen, Krishnamoorthy, \& Wright, 2008). The institutional theory also has an unspecified prediction on whether the audit committee will be friends with managers or the auditor in disagreements that the auditors may have with managers. For instance, the audit committees habitually fulfill a key figurative role that in practice might lead the members to legitimize their roles by querying the management.

\section{Audit Committee Size and Auditors Brand Name}

It has been argued that larger audit committee has a high likelihood of enriching its status and power in a firm, thus demanding a high quality audit (Kalbers \& Fogarty, 1993). This has been confirmed by Akhalumeh et al. (2017) who studied the effect of corporate governance on audit quality in Nigeria. They find that the larger board is significantly and positively related to Big 4 auditors. This indicates that larger board requests for better audit assurance by purchasing the service of Big 4 auditors. In addition, Ejeagbasi et al. (2015) studied the effect of corporate governance and audit quality in Nigeria. They showed that larger board size is positively and significantly related to Big 4 auditors. They contend that larger boards demand for better audit assurance by employing Big 4 auditors. The result has validated the finding of Chen and Zhou (2007) who examined the influence of audit committee and board attributes on auditor change decisions by Andersen's clients. They showed that larger audit committee is more likely to engage the Big 4 auditors in the selection of successor auditors. In line with the foregoing, the study hypothesized that: 
$H_{1}$ Audit committee size has a positive significant relationship with Big 4 auditors.

\section{Audit Committee Independence and Auditors Brand Name}

It has been argued that audit committee that is independent of management does not have a private or economic dependence on managers. Consequently, agency theory suggests that an independent audit committee may be more prepared to disagree with management on diverse issues (Abbott, Parker, Peters \& Raghunandan, 2003; Carcello \& Neal, 2003). Thus, throughout the evaluation of the audit program and results thereof, an independent audit committee may demand for a comprehensive audit scope in order to escape being connected to a financial misstatement and preserve reputational capital (Abbott et al., 2003; Carcello \& Neal, 2003). The foregoing argument have been confirmed by a recent study of Jiraporn, Chintrakarn, Tong and Treepongkaruna (2018) who examined whether board independence can be substituted with external audit quality. They employed a sample of 14,000 firm-year observations for 18 years. They demonstrated that firms that have larger percentage of independent directors on the board have less chance of employing Big 4 auditors. This suggested that robust board with greater proportion of independence directors gain more active governance and thus do not require as much from external auditors. More so, Ejeagbasi et al. (2015) found that audit committee independence is positively and significantly linked to Big 4 auditors. This has been confirmed by Akhalumeh et al. (2017) who revealed that board independence is positively and significantly associated to Big 4 auditors. This indicates that larger percentage of independent directors in the audit committee demand for higher audit assurance by employing Big 4 auditors. In line with the foregoing arguments it is hypothesized that:

$\mathrm{H}_{2}$ Audit committee independence has a positive significant relationship with Big 4 auditors.

\section{Audit Committee Meetings and Auditors Brand Name}

It has been argued that audit committee that meets at least twice biannually has more likelihood of engaging an industry specialist auditor (Abbott et al., 2003). Prior literature has shown that audit committee's frequent meeting is positively associated to audit quality 
(Lee \& Mande, 2005). The above arguments have been empirically confirmed by Chen and Zhou (2007) who showed that audit committee that meets frequently has a high likelihood of engaging Big 4 auditors in the selection of successor auditors. This is consistent with the notion that the audit committee that meets frequently are more likely to purchase high audit quality in their quest for greater assurance. In contrast, Sharma et al. (2009) found an inverse relationship between audit committee meetings and Big 4 auditors. Their finding supports the substitutional hypothesis of audit quality, which suggests that effective governance devices can serve as substitutes to external monitoring provided by external auditors. In line with the above argument the study hypothesized that:

$\mathrm{H}_{3}$ Audit committee meeting has a positive significant relationship with Big 4 auditors.

\section{Audit Committee Expertise and Auditors Brand Name}

The proponents of institutional theory have argued that a company's audit committee whose members have specific industry skill is linked to higher financial reporting quality. Accordingly, if managers and audit committee of such company work on the same board within the similar industry, this association may expand the committee's expertise and subsequently improve its general skill to act as effective monitors (Cohen et al., 2014). This has been confirmed by Kim, Kwak, Lim and Yu (2017) who demonstrated that audit committee financial accounting experts enhances audit quality. This suggests that increasing the proportion of financial accounting experts in audit committee brings about an additional increase in effort in order to enhance external monitoring. This has validated the finding of Chen and Zhou (2007) who revealed that proportion of financial expertise in audit committee increases the chance of selecting Big 4 auditors. In another development, it has been argued that legal experts serve as monitors rather than mere signal to financial reporting quality. This is because, Baxter and Cotter (2009) have affirmed that legal expertise on the company's audit committee significantly reduce the practice of earnings management and thus enhance audit quality. Therefore, their legal knowledge allows them to be more familiar with litigation threats relating to financial reporting issues. $\mathrm{H}_{4}$ Audit committee financial accounting expert has a positive significant relationship with Big 4 auditors. $\mathrm{H}_{5}$ Audit committee legal expert has a positive significant relationship with Big 4 auditors. 


\section{Female Audit Committee Member and Auditors Brand Name}

It has been contended that female directors in the boards are more ready for board meetings than the male counterparts. Thus, high proportion of female directors may improve board actions and effectiveness (Huse \& Solberg, 2006). Prior literature has showed that female audit committee members demand better audit efforts than their male colleagues. This has been empirically affirmed by Lai, Srinidhi and Tsui (2017) who showed that female directors in audit committee demand greater audit quality than the male directors in US firms. This is not surprising since liberal feminist theory suggests that if females would be given equal chances, males and females will develop their potential judiciously and more equally. Consequently, their psychological distinctions will decrease and later fade (Fischer et al.,1993). This has been confirmed by Aldamen et al. (2016) who suggest that a divergent gender in audit committee demands a higher quality audit in a high risk environment.

$\mathrm{H}_{6}$ Female audit committee member has a positive significant relationship with Big 4 auditors.

\section{Audit Committee Stock Ownership and Auditors Brand Name}

The advocates of agency theory have argued that independent external auditors are demanded due to a desire to reduce agency cost arising from asymmetric information between stockholders and managers. This has been empirically confirmed by previous studies (DeFond, 1992; Menon \& Williams, 1994). Prior literature on audit committee stock ownership has contended that larger percentage of shares possessed by audit committee significantly decreases the chance that the auditor provides a going concern report for economically troubled companies and auditor dismissal (Bronson, Carcello, Hollingsworth \& Neal, 2009; Hamdan, Mushtaha \& AlSartawi, 2013; Vafeas, 2005). In addition, Ejeagbasi et al. (2015) found that ownership concentration has a positive relationship with the Big 4 auditors. Furthermore Adam and Bala (2015) examined ownership structure and audit quality in Nigeria. Their study indicated that director's ownership has a positive significant association with audit quality of listed banks in Nigeria. They suggest that a higher percentage of directors' ownership enhance their monitoring role by providing greater audit assurance through engaging better auditors. In addition, with the foregoing, the study hypothesized that: $H_{7}$ Audit committee stock ownership has a positive significant relationship with Big 4 auditors. 


\section{Audit Committee Tenure and Auditors Brand Name}

The proponents of agency theory have argued that the longer it takes for a director to serve on the board, the more informed he will be about the entity's practices and hence become more active in preventing the incidence of financial reporting fraud (Beasley, 1996; Hermalin \& Weisbach, 1991; Vafeas 2005). This suggests that audit committee tenure has positive influence on audit quality. Moreover, it has been contended that the positive association of long serving directors on monitoring effectiveness compensates the negative association predominantly when it comes to overseeing financial reporting process.Thus resulting in long serving board members who are independent to managers could have greater governance quality since they might be more watchful with reputational capitals and thus acquire more audit efforts (Chan, Liu \& Sun, 2013; Vafeas, 2003). This suggests the external audit might complement to audit committee governance and as a result, there might be a positive relationship between the percentage of long serving directors on the audit committee and audit fees. Thus, external auditors might price audit committee's effectiveness, for instance, audit committee's governance may substitute with external auditing. In addition, it has been contended that external auditors can devote fewer efforts on clients with a high percentage of long serving directors on the independent audit committee in circumstances where long tenure directors have superior monitoring effectiveness (Chan, Liu \& Sun, 2013). This suggests that long tenure directors might have a lesser request for audit efforts. From the above argument, it is expected that long tenure directors may request fewer audit efforts. In the light of the foregoing arguments, the study hypothesized that:

$\mathrm{H}_{8}$ Audit committee tenure has a positive significant relationship with Big 4 auditors.

\section{Audit Committee Chair and Auditors Brand Name}

Previous studies on audit committee chair have established that audit committee chair gains control over audit committee, as they plan for the agendas and control the information flow (Sharma et al., 2009). This has been empirically confirmed by Bruynseels and Cardinaels (2014) who explored whether audit committee is 
a manager's watchdog or a personal colleague of the CEOs. They utilized a sample of listed firms for five years from 2004 to 2008. They revealed that audit committees who have social network to the CEO purchase less audit services and participate more in earnings management. They also suggested that the external auditors of such companies whose audit committee have social network with managers are less likely to provide going-concern opinions or to disclose internal control weakness. This has been confirmed by a recent study by Qu (2018) who showed that audit committee chair vary from ordinary members of the committee as they are commonly in charge of more official responsibilities including schedule for the committees' meetings, setting the agenda, and collaborating with the internal and external auditors. In line with the above arguments the study hypothesized that:

$\mathrm{H}_{9}$ Audit committee chair has a positive significant relationship with Big 4 auditors.

Audit Committee (AC) Attributes and Auditor Brand Name

Audit Committee Attributes

Auditor Brand Name

AC Size

AC Independence

AC Meetings

AC Financial Accounting Expert

AC Legal Expert

Female AC Member

AC Stock Ownership

AC Tenure

AC Chair

Figure 1. Conceptual framework.

\section{Methodology}

The population consist of 170 listed firms in the Nigerian Stock Exchange (NSE) as at $31^{\text {st }}$ December 2016. From the total, 55 firms were identified as financial institutions thus; they had left out a total of 115 firms. Without considering the 15 firms that were delisted by 
NSE in 2016, there were 100 firms left. Out of these 100 firms, 12 firms did not provide complete information. Therefore, a final sample of 88 firms was employed in this current study. The duration of this study ranged from 2012 to 2016 . The data for the study were obtained from the annual reports of the listed firms and Thompson Reuters DataStream. Table 1 presents the description of how the sample was generated.

Table 1

Sample Computation for Firms that Meet the Filtering Process

\begin{tabular}{lcc}
\hline Sample computation for year 2012 to 2016 & Firms & $\begin{array}{c}\text { Firm-year } \\
\text { observations }\end{array}$ \\
\hline Total population & 170 & 850 \\
Less: & $\underline{55}$ & $\underline{275}$ \\
Financial Services & 115 & 575 \\
Total Non-financial Service Firms & 15 & 75 \\
Less: & $\underline{12}$ & $\underline{60}$ \\
Firms Delisted by NSE IN 2016 & $\underline{88}$ & $\underline{440}$ \\
$\begin{array}{l}\text { Firms that did not provide complete } \\
\text { information }\end{array}$ & & \\
Final sampled firms & & \\
Source. NSE, 2016 &
\end{tabular}

\section{Variable Measurement and Model Specification}

Various measurements have been employed as proxies for individual audit committee attributes. Some prior literature have used dummy variables zero and one (Cohen, Hoitash, Krishnamoorthy \& Wright, 2014; Dhaliwal, Naiker \& Navissi, 2010; Sultana, Mitchell \& Zahn, 2013; Zaman, Hudaib \& Haniffa, 2011). Other studies have employed aggregate numbers of individual surrogates or ratios of the surrogates to the total number of audit committee members (Nelson \& Devi, 2013; Saleh, Iskandar, \& Rahmat, 2007; Sultana, 2015). Consistent with prior studies (Abernathy et al., 2014; Xie et al., 2003; Klein, 2002; Krishnan et al., 2011; Yermack, 2004), this study employed an aggregate number of audit committee members in some of the committee's characteristics and ratios for some of the 
committees' attributes to the aggregate numbers of the committees' members. Following AlQadasi and Abidin (2018), Bala, Amran and Shaari (2018), Sani, Latif \& Al-Dhamari (2018) and Zhang et al. (2007), auditor brand name is measured as a dummy variable 1 when a firm is audited by Big 4 auditors and 0 when a firm is audited by a nonBig 4 auditors. The study used some variables as a control for the company's specific characteristics and governance characteristics that have been employed by prior studies (Abernathy et al., 2014; Badolato et al., 2014; Beasley, 1996; Garba \& Mohamed 2018; Krishnan et al., 2011; Saleh et al., 2007; Sultana, 2015). To ensure precision, the control variables of this study included firm size (FS), leverage (LEV), firm age (FAGE), board financial expertise (BF), board independence (BI) and sales growth (SGROWTH). Following Krishnan et al. (2011) and Badolato et al. (2014), we controlled two governance characteristics which are the board expertise and the board which have been affirmed to have a significant effect on monitoring effectiveness and endorsing financial reporting process (Carcello \& Neal, 2003; Klein, 2002). Therefore, the study expected that the board expertise has a positive significant influence with Big 4 auditors. Additionally, it has been confirmed that a larger proportion of independent directors on the boards increases the likelihood of audit quality (Alves, 2014; 2005; Klein, 2002). Consistent with the above arguments, the study has projected a positive and significant association between board independence and Big 4 auditors.

Similarly, the study also controlled the firm size which was proxied by the natural logarithm of total assets and, leverage was proxied by the total debt to total equity ratio. It has been contended that larger companies are linked to higher financial reporting quality as they are more closely supervised in the market (Bala \& Kumai, 2015; Klein, 2002). Thus, we expect a positive significant association between firm size and Big 4 auditors. Furthermore, prior literature showed that highly leveraged companies are connected with a higher level of asymmetric timeliness of accruals which, in return, reduces the quality of financial reporting process (Klein, 2002; Krishnan et al., 2011; Sultana et al., 2013). In line with with (Bala, Amran \& Shaari, 2018) and Chen et al. (2010) we expect a positive association between sales growth and Big 4 auditors. Finally, consistent with Leung, Srinidhi and Xie (2017), we controlled for Firm age and has presumed a positive association between older firms and Big 4 auditors. The details of measurement of variables and their definitions are presented in Table 2. 
IJMS 25 (2), 39-70 (2018)

Table 2

Summary of Independent Variable Measurement

\begin{tabular}{|c|c|c|c|}
\hline Variable & Hypotheses & Acronyms & Measurement \\
\hline \multicolumn{4}{|l|}{$\begin{array}{l}\text { Independent } \\
\text { variables }\end{array}$} \\
\hline AC Size & $\mathrm{H}_{1}$ & ACSIZ & $\begin{array}{l}\text { Aggregate number of audit } \\
\text { committee members }\end{array}$ \\
\hline AC Independence & $\mathrm{H}_{2}$ & ACIDP & $\begin{array}{l}\text { Proportion of independent } \\
\text { non-executive directors in } \\
\text { audit }\end{array}$ \\
\hline AC Meetings & $\mathrm{H}_{3}$ & ACMET & $\begin{array}{l}\text { Frequency of meetings held } \\
\text { by audit committee }\end{array}$ \\
\hline $\begin{array}{l}\text { AC Financial } \\
\text { Accounting Experts }\end{array}$ & $\mathrm{H}_{4}$ & ACFAEX & $\begin{array}{l}\text { Ration of audit committee } \\
\text { members who qualified as } \\
\text { professional accountants } \\
\text { with certificates Association } \\
\text { of National Accountants } \\
\text { of Nigeria, Institute of } \\
\text { Chartered Accountants of } \\
\text { Nigeria or their equivalent } \\
\text { to the total number of audit } \\
\text { committee members }\end{array}$ \\
\hline AC Legal Expert & $\mathrm{H}_{5}$ & ACLEX & $\begin{array}{l}\text { Ration of audit committee } \\
\text { members with legal } \\
\text { backgrounds; Bachelors of } \\
\text { Laws, Masters in Laws, } \\
\text { members of Nigerian Bar } \\
\text { Association to the total } \\
\text { number of audit committee } \\
\text { members }\end{array}$ \\
\hline Female AC Member & $\mathrm{H}_{6}$ & FACME & $\begin{array}{l}\text { Proportion of female } \\
\text { directors on audit committee }\end{array}$ \\
\hline $\begin{array}{l}\text { AC Stock } \\
\text { Ownership }\end{array}$ & $\mathrm{H}_{7}$ & ACSOW & $\begin{array}{l}\text { Aggregate number of shares } \\
\text { held by audit committee } \\
\text { members }\end{array}$ \\
\hline AC Tenure & $\mathrm{H}_{8}$ & ACTNR & $\begin{array}{l}\text { Average tenure of audit } \\
\text { committee members }\end{array}$ \\
\hline
\end{tabular}

(continued) 
IJMS 25 (2), 39-70 (2018)

\begin{tabular}{lccl}
\hline Variable & Hypotheses & Acronyms & \multicolumn{1}{c}{ Measurement } \\
\hline AC Chair & $\mathrm{H}_{9}$ & ACCHR & $\begin{array}{l}\text { Dummy variable computed } \\
\text { as one if the audit committee }\end{array}$ \\
& & $\begin{array}{l}\text { is chaired by a shareholder } \\
\text { and zero otherwise }\end{array}$
\end{tabular}

Dependent Variable

Auditor Brand

Name

AUBRN

BFEX

BID

Independence

Firm Size

Leverage

Firm Age

Sales Growth
FSIZ

LEVR

FAGE

SGROWTH
Dummy variable computed as one if a firm is audited by big 4 and zero otherwise

Proportion of board members with financial knowledge

Proportion of independent directors on the board

Natural logarithm of total asset

Long-term debt to total equity

Computed as year of observation minus year of listing

Change in sales divided by sales in previous year

\section{Model Specification}

The hypotheses of the study were tested using the following logistic model:

$$
\begin{aligned}
& \text { AUBRN }=\beta_{0}+\beta_{1} \mathrm{ACSIZ}_{\text {it }}+\beta_{2} \mathrm{ACIDP}_{\text {it }}+\beta_{3} \mathrm{ACMET}_{\text {it }}+\beta_{4} \mathrm{ACFAEX}_{\mathrm{it}} \\
& +\beta_{5} \text { ACLEX }_{\mathrm{it}}+\beta_{6} \mathrm{FACME}_{\mathrm{it}}+\beta_{7} \mathrm{ACSOW}_{\mathrm{it}}+\beta_{8} \mathrm{ACTNR}_{\mathrm{it}} \beta_{9} \mathrm{ACCHR}_{\mathrm{it}}+ \\
& \beta_{10} \text { BFEX }_{\text {it }}+\beta_{11} \text { BID }_{\text {it }}+\beta_{12} \text { FSIZ }_{\text {it }}+\beta_{13} \text { LEVR }_{\text {it }}+\beta_{14} \text { FAGE }_{\text {it }} \beta_{15} \text { SGROWTH }_{\text {it }} \\
& +\varepsilon_{\text {it }}
\end{aligned}
$$


IJMS 25 (2), 39-70 (2018)

\section{Results and Discussions}

\section{Descriptive Statistics}

Table 3 presents the descriptive statistics of the studied variables. Following prior studies, we utilized continuous variables with outsized observations at $5 \%$ or $95 \%$ confidence intervals to control the outliers in the data (Barth, Landsman, Lang \& Williams, 2012; Ittonen, Miettinen, Vähämaa \& Miettinen, 2010; Yang \& Krishnan, 2005). Table 3 shows that the mean of audit committee size (ACSIZ) was five members, alternating from four o six. On average, $43 \%$ of audit committees had independent directors, fluctuating from $25 \%$ and $50 \%$. The committees met at least four times annually. On average, $21 \%$ of audit committee members had financial accounting experts. While some firms did not have any members with financial accounting expertise, other firms had up to $50 \%$ financial accounting experts in the committees. A mean of $10 \%$ of audit committee members had legal expertise (ACLEX), with some firms having up to $29 \%$. An average of $54 \%$ of audit committee members had female directors while some firms did not have female representation.

Table 3

Descriptive Statistics

\begin{tabular}{lrrrrr}
\hline Variable & Obs & Mean & Std. Dev. & Min & Max \\
\hline AUBRN & 440 & 0.58 & 0.49 & 0.00 & 1.00 \\
ACSIZ & 440 & 5.47 & 0.86 & 4.00 & 6.00 \\
ACIDP & 440 & 0.43 & 0.09 & 0.25 & 0.50 \\
ACMET & 440 & 3.79 & 0.62 & 3.00 & 5.00 \\
ACFAEX & 440 & 0.21 & 0.13 & 0.00 & 0.50 \\
ACLEX & 440 & 0.10 & 0.09 & 0.00 & 0.29 \\
FACME & 440 & 0.54 & 0.50 & 0.00 & 1.00 \\
ACSOW (Units) & 440 & $37,800,000$ & 79100000 & $12,768.00$ & $300,000,000$ \\
ACTNR & 440 & 5.11 & 1.44 & 3.00 & 8.00 \\
\hline & & & & & $($ continued)
\end{tabular}


IJMS 25 (2), 39-70 (2018)

\begin{tabular}{lcrrrr}
\hline Variable & Obs & Mean & Std. Dev. & Min & Max \\
\hline ACCHR & 440 & 0.89 & 0.31 & 0.00 & 1.00 \\
BID & 440 & 0.72 & 0.11 & 0.06 & 0.92 \\
BFEX & 440 & 0.50 & 0.16 & 0.00 & 0.88 \\
FSIZ & 440 & 16.42 & 1.59 & 13.76 & 19.45 \\
LEVR & 440 & 0.01 & 0.02 & 0.00 & 0.07 \\
FAGE & 440 & 23.82 & 13.29 & 4.00 & 42.00 \\
SGROWTH & 440 & 0.27 & 2.64 & -5.26 & 7.51 \\
\hline
\end{tabular}

Notes: AUBRN = Big 4 auditors (KPMG, Price Waterhouse Coopers, Ernst \& Young and Deloitte). $\mathrm{ACSIZ}=\mathrm{AC}$ size, $\mathrm{ACIDP}=\mathrm{AC}$ independence, $\mathrm{ACMET}=\mathrm{AC}$ meetings, ACFAEX $=$ AC financial expertise, $\mathrm{ACLEX}=\mathrm{AC}$ legal expert, $\mathrm{FACME}=$ female $\mathrm{AC}$ member, $\mathrm{ACSOW}=\mathrm{AC}$ stock ownership, $\mathrm{ACTNR}=\mathrm{AC}$ tenure, $\mathrm{ACCHR}=\mathrm{AC}$ chair independence, $\mathrm{BID}=$ board independence, $\mathrm{BFEX}=$ board expertise, $\mathrm{FSIZ}=$ firm size LEVR $=$ leverage, FAGE = firm age, $\mathrm{SGROWTH}=$ sales growth.

Audit committee stock ownership (ACSOW) extended from 12,768 units to $300,000,000$ units, with a mean of $37,800,000$ units. Audit committee tenure (ACTNR) was on average five years, extending from three to eight years. While in some firms, the audit committee were chaired by directors, but majority were chaired by the shareholders' representatives. This is one of the unique attributes of audit committee formation in Nigeria, because it is a requirement by the Companies and Allied Matters Acts of Nigeria (2004) that audit committee members should be composed of equal representation from both the shareholders and the directors.

\section{Correlations}

Table 4 depicts the correlation matrix for variables of the study. Largely, the results show that multicollinearity does not stance a threat to the estimation variables. The highest correlations among the independent variables were $48 \%$ and $45 \%$ between ACMET and ACSIZ as well as FSIZ and ACSIZ, respectively. These correlations may be considered normal because Hair, Black, Barry, Babin and Anderson (2014) have argued that a correlation of less than $90 \%$ may not be a problematical for estimation. On one hand, ACIDP, ACFAEX ACLEX, FACME, and ACSOW were positively correlated with AUBRN. The positive coefficients might mirror the nature of their effect in the regression estimates. Alternatively, ACSIZ, ACMET, ACTNR and ACCHR were negatively correlated with AUBRN. 
IJMS 25 (2), 39-70 (2018)

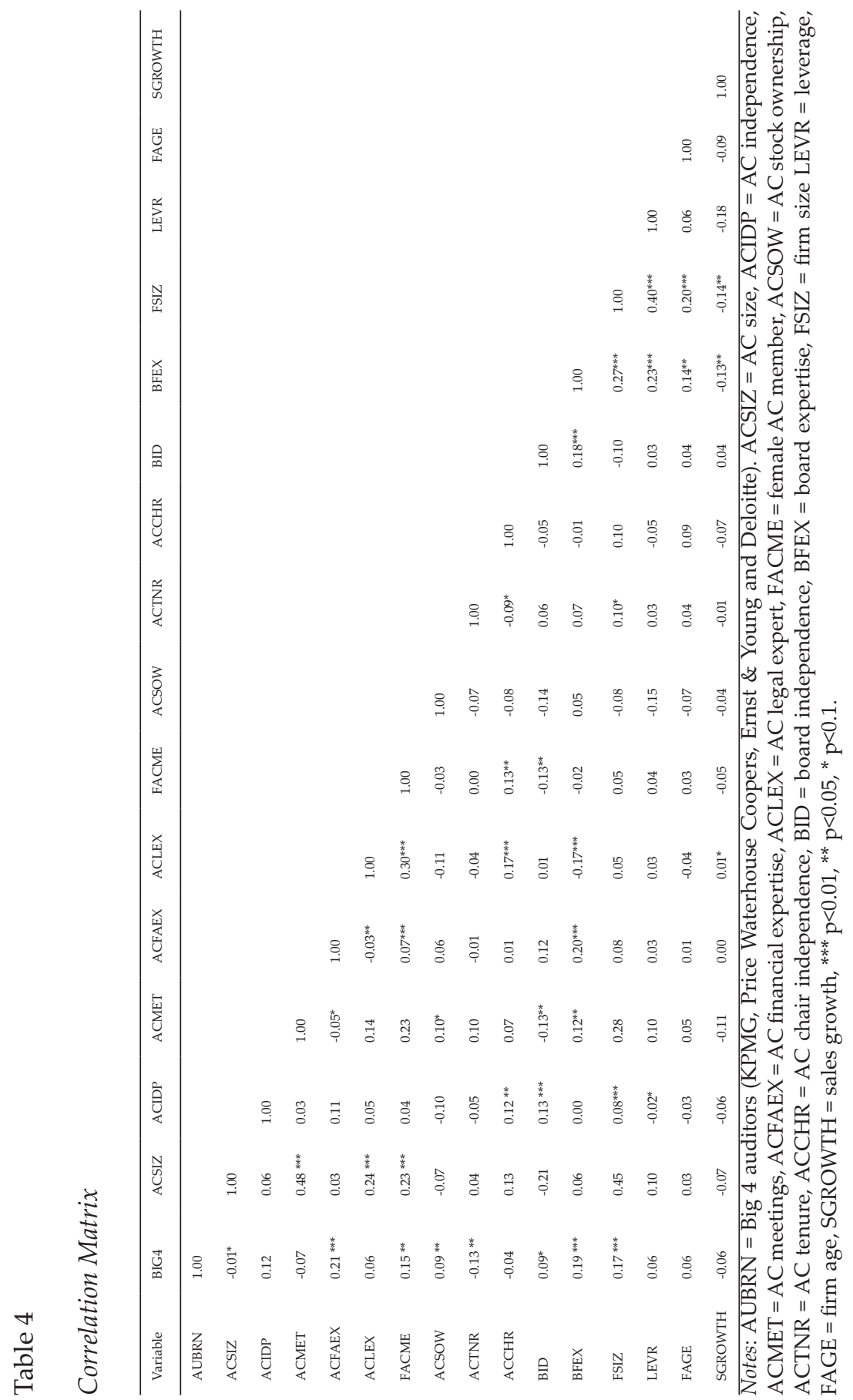


IJMS 25 (2), 39-70 (2018)

\section{Multivariate Analysis}

\section{Relationship between of Audit Committee Attributes and Auditor Brand Name}

This section examines the hypotheses of the study $\left(H_{1-} H_{9}\right)$ to determine the effect of audit committee attributes and AUBRN. Table 5 shows the regression results of the relationship between audit committee attributes and AUBRN. Table 5 shows that ACSIZ had a positive insignificant relationship with AUBRN. This implies that a larger audit committee might not contribute in the selection of auditors' brand name in the Nigerian listed firms. The finding was contrary to the study expectation $\left(H_{1}\right)$ which assumed that ACSIZ has a positive association with AUBRN. This could be a result of the fact that larger ACSIZ may be too difficult to manage as too large members may possibly result in a slower decision-making progress. The findings also show that ACIDP had a positive significant association with AUBRN at 5\% significance level. This proposes that a larger proportion of independent directors in the audit committee increases the probability that a firm will engage Big 4 auditors, further supporting $\left(\mathrm{H}_{2}\right)$, which anticipated a positive relationship between audit committee attributes and AUBRN.

Table 5

Panel Regression on the Relationship between Audit Committee Attributes and AUBRN

\begin{tabular}{lccccc}
\hline AUBRN & Hypotheses(sign) & Coef. & Std. Err. & z-val. & p-val. \\
\hline ACSIZ & $\mathrm{H}_{1}(+)$ & -0.18 & 0.18 & -1.00 & 0.32 \\
ACIDP & $\mathrm{H}_{2}(+)$ & 2.57 & 1.27 & $2.02^{* *}$ & 0.04 \\
ACMET & $\mathrm{H}_{3}(+)$ & -0.76 & 0.24 & $-3.12^{* * *}$ & 0.00 \\
ACFAEX & $\mathrm{H}_{4}(+)$ & 2.53 & 0.92 & $2.75^{* * *}$ & 0.01 \\
ACLEX & $\mathrm{H}_{5}(+)$ & 2.56 & 1.44 & $1.78^{*}$ & 0.08 \\
FACME & $\mathrm{H}_{6}(+)$ & 0.95 & 0.26 & $3.67^{* * *}$ & 0.00 \\
ACSOW & $\mathrm{H}_{7}(+)$ & 0.00 & 0.00 & $2.40^{* *}$ & 0.02 \\
ACTNR & $\mathrm{H}_{8}(+)$ & -0.25 & 0.08 & $-3.04^{* * *}$ & 0.00 \\
ACCHR & $\mathrm{H}_{9}(+)$ & -0.83 & 0.39 & $-2.10^{* *}$ & 0.04 \\
BID & & 1.97 & 1.11 & $1.77^{*}$ & 0.08 \\
\hline & & & & & (continued)
\end{tabular}


IJMS 25 (2), 39-70 (2018)

\begin{tabular}{|c|c|c|c|c|c|}
\hline AUBRN & Hypotheses(sign) & Coef. & Std. Err. & z-val. & p-val. \\
\hline BFEX & & 2.23 & 0.83 & $2.68^{* * *}$ & 0.01 \\
\hline FSIZ & & 0.40 & 0.10 & $4.06^{* * *}$ & 0.00 \\
\hline LEVR & & -7.70 & 6.81 & -1.13 & 0.26 \\
\hline FAGE & & 0.00 & 0.01 & 0.43 & 0.67 \\
\hline SGROWTH & & -0.03 & 0.04 & -0.77 & 0.44 \\
\hline Cons & & -5.31 & 1.76 & $-3.02^{* * *}$ & 0.00 \\
\hline Pseudo R2 & & 0.15 & & & \\
\hline LR chi2(15) & & 91.31 & & & \\
\hline Prob $>$ chi 2 & & 0.00 & & & \\
\hline Correctly & & $70.68 \%$ & & & \\
\hline \multicolumn{6}{|l|}{ Specified } \\
\hline Hosmer- & & 2.42 & & & \\
\hline \multicolumn{6}{|l|}{$\begin{array}{l}\text { Lemeshow } \\
\text { chi2 }\end{array}$} \\
\hline Prob > chi 2 & & 0.97 & & & \\
\hline
\end{tabular}

Notes: AUBRN = Big 4 auditors (KPMG, Price Waterhouse Coopers, Ernst \& Young and Deloitte). $\mathrm{ACSIZ}=\mathrm{AC}$ size, $\mathrm{ACIDP}=\mathrm{AC}$ independence, $\mathrm{ACMET}=\mathrm{AC}$ meetings, ACFAEX $=$ AC financial expertise, $\mathrm{ACLEX}=\mathrm{AC}$ legal expert, $\mathrm{FACME}=$ female $\mathrm{AC}$ member, $\mathrm{ACSOW}=\mathrm{AC}$ stock ownership, $\mathrm{ACTNR}=\mathrm{AC}$ tenure, $\mathrm{ACCHR}=\mathrm{AC}$ chair independence, $\mathrm{BID}=$ board independence, $\mathrm{BFEX}=$ board expertise, $\mathrm{FSIZ}=$ firm size LEVR $=$ leverage, FAGE $=$ firm age, SGROWTH $=$ sales growth, ${ }^{* * *} \mathrm{p}<0.01,{ }^{* *} \mathrm{p}<0.05$, * $\mathrm{p}<0.1$.

This encourages the audit committee to purchase high quality auditing services and be more passionate to reduce the propensity of financial reporting frauds. The result is consistent with the agency theory which proposes that audit committee which is independent of managers might be more willing to disagree with managers about dissimilar issues (Abbott et al., 2003; Carcello \& Neal, 2003). Thus, making them to be more watchful on financial reporting issues. This supports the findings of Beasley (1996), Hudaib and Cooke (2005) and Ejeagbasi et al. (2015) who found positive association between ACIDP and AUBRN.

Contrary to the our expectation $\left(H_{3}\right)$, ACMET was found to have an inverse significant relationship with AUBRN. This suggests that, more frequency of ACMET decreases the likelihood of employing Big 4 auditors. This finding supports the substitution hypothesis of audit quality which proposes an inverse association between governance 
instruments and audit quality. A likely reason for this could be that audit committee which meets frequently can stimulate audit coverage through the various steps of the audits. Consequently, there is a high probability that more recurrent audit committee meetings may reduce the accidental issues of financial frauds in a firm and thus qualifying them to demand less audit efforts. This finding validates previous studies (Abbott et al., 2004; Raghunandan, Read \& Rama, 2001) who found that regular audit committee meetings reduced the extent of financial restatement because such meetings with the internal auditors will allow them to be kept informed and acquainted with the accounting and auditing issues. In addition, Sharma et al. (2009) found an inverse relationship between audit committee meetings and Big 4 auditors.

ACFAEX had a positive significant association with AUBRN at $1 \%$ significance level. The result is in line with the study expectation $\left(H_{4}\right)$, which hypothesized that ACFAEX has a positive significant association with AUBRN. This deduced that audit committee members with financial accounting knowledge are highly likely to purchase the services of Big 4 auditors in their quest for greater assurance. This result is consistent with the complementary hypothesis of audit that is linked to agency theory which proposes that auditing service is needed to minimize agency conflicts rising from the interest of stockholders and managers. Consequently, audit committee members with financial accounting knowledge are more willing to engage better auditors who will in turn be more effective monitors on managers' actions and thus confirm that appropriate financial report and disclosure exist. This supports the findings of Abbott et al. (2003), Carcello and Neal (2003) and Kim (2015) who revealed that ACFAEX is significantly associated to the likelihood of hiring high quality auditors such as Big 4 auditors or industry specialist auditors. Interestingly, it is apparent that ACLEX had a positive significant association with AUBRN. This suggests that audit committee members with legal backgrounds have a probability of engaging Big 4 auditors. The result supports the study hypothesis $\left(H_{5}\right)$, which presumes that ACLEX has a positive relationship with AUBRN. This is in line with institutional theory which proposes that audit committee that has members with specific expertise is related to higher financial reporting quality (Cohen et al., 2014). This is not astonishing as audit committee members with legal experience 
prepare the committee to be more cautious about legal risks that are connected to erroneous or poor aggressive financial reports. This results in the employment of the services of better auditors such as the Big 4 auditors in order to acquire better audit assurance. This supports the findings of Krishnan et al. (2011) who revealed that legal experts in the audit committee may assist in ensuring better financial reporting as financial reporting quality can be linked to legal liability threats and their legal experiences required them to be more vigilant about such threats.

Table 5 also reveals that FACME had a positive significant association with the AUBRN at 1\% significance level. This suggests that the existence of at least a female director in the audit committee increases the likelihood of choosing the services of Big 4 auditors than the nonBig 4 auditors in the listed firms in Nigeria. The finding is in line with the study expectation $\left(H_{6}\right)$, which assumes that FACME has a positive significant association with AUBRN. The result is consistent with the perception that a diverse gender in audit committee demands for a higher quality audit in high risk environments. The result is in line with the findings of Aldamen et al. (2016), Huang and Thiruvadi (2010) and Lai et al. (2017) who showed that FACME request for a high audit quality to obtain a better audit assurance. ACSOW had a positive significant association with AUBRN at the 5\% significance level. This infers that unit of shares controlled by audit committee members increases the probability of selecting Big 4 auditors other than non-Big 4 auditors. This is consistent with agency perspective which proposes that the monitoring role offers by ACSOW makes them to demand greater audit assurance by engaging better auditors. The finding support the study hypothesis $\left(\mathrm{H}_{6}\right)$, which presumes that ACSOW has a positive significant association with AUBRN. The result is in line with the finding of Kibiya et al. (2016) who revealed that increasing the percentage of shares held by audit committee improves their monitoring role and enhances financial reporting quality.

Contrary to our expectation $\left(H_{7}\right)$, it is found that ACTNR had a negative significant association with AUBRN. This suggests that long serving directors are less likely to employ Big 4 auditors. Possible explanation for this might be that long serving directors can have greater knowledge, skill and potential to perform better. This makes 
them to require less desire for greater external monitoring offered by Big 4 auditors. This is consistent with the substitution effect hypothesis which proposes an inverse association between governance devices and audit quality. The result also confirms the arguments of agency theory proponents who advocate that long tenure directors are more acquainted and informed about the firms practices and thus becoming more effective in reducing the incident of financial reporting fraud (Beasley, 1996; Hermalin \& Weisbach, 1991; Vafeas 2005). ACCHR had a negative significant association with Big 4 auditors. This proposes that the chairmanship of shareholders in AC decreases the likelihood of employing Big 4 auditors. The result is contrary to our prior expectation which hypothesized that ACCHR has a positive association with AUBRN. This result is consistent with the findings of prior studies (Sharma et al., 2009) who found that audit chair gains control over audit committee, schedule for the agendas and controls the information flow. This makes them to have less desire for high audit efforts.

\section{Sensitivity Analysis}

To assess the sensitivity of the results and to confirm that the findings were not sensitive to endogeneity and the choice of alternative measurements of the independent variables sensitivity tests were conducted. The following subsections present the results of the sensitivity analysis used by the study.

\section{Alternative Measurements of Independent Variables}

This section presents alternative measurements of the independent variables of the study. The alternative measurements are considered to act as sensitivity checks. Recalled that seven predictor variables were measured as continuous variables in the main analysis (ACSIZ, ACIDP, ACMET, ACFAEX, ACLEX, ACTNR, and ACSOW). However, we used dichotomous measures for these variables in the sensitivity analysis following AlQadasi and Abidin (2018), Krishnan et al. (2011), Xie et al. (2003) and Zhang et al. (2007). Table 6 shows the results of alternative measurement of independent variables for the sensitivity test. Results reveal that the signs and coefficients of the main analysis are similar to those of sensitivity checks. Thus, it is established that our findings for the main model are insensitive to alternative measurement for the independent variables. 
IJMS 25 (2), 39-70 (2018)

Table 6

Pool Results of the Alternative Measures of Independent Variable

\begin{tabular}{|c|c|c|}
\hline VARIABLES & Hypotheses and Expected Signs & Coef. and t-values \\
\hline ACSIZ & $\mathrm{H}_{1}(+)$ & $\begin{array}{l}-0.597^{* *} \\
(0.303)\end{array}$ \\
\hline ACIDP & $\mathrm{H}_{2}(+)$ & $\begin{array}{c}1.940 \\
(1.189)\end{array}$ \\
\hline ACMET & $\mathrm{H}_{3}(+)$ & $\begin{array}{l}-0.350 \\
(0.343)\end{array}$ \\
\hline ACFAEX & $\mathrm{H}_{4}(+)$ & $\begin{array}{l}1.175^{* * *} \\
(0.336)\end{array}$ \\
\hline ACLEX & $\mathrm{H}_{5}(+)$ & $\begin{array}{c}0.346 \\
(0.243)\end{array}$ \\
\hline FACME & $\mathrm{H}_{6}(+)$ & $\begin{array}{c}2.075^{*} \\
(1.165)\end{array}$ \\
\hline ACSOW & $\mathrm{H}_{7}(+)$ & $\begin{array}{l}-0.723^{* * *} \\
(0.226)\end{array}$ \\
\hline ACTNR & $\mathrm{H}_{8}(+)$ & $\begin{array}{l}-0.638^{*} \\
(0.367)\end{array}$ \\
\hline ACCHR & $\mathrm{H}_{9}(+)$ & $\begin{array}{c}1.425 \\
(1.051)\end{array}$ \\
\hline BID & & $\begin{array}{c}1.535^{*} \\
(0.795)\end{array}$ \\
\hline BFEX & & $\begin{array}{c}0.303^{* * *} \\
(0.0816)\end{array}$ \\
\hline FSIZ & & $\begin{array}{l}-3.926 \\
(6.257)\end{array}$ \\
\hline LEVR & & $\begin{array}{c}0.00713 \\
(0.00827)\end{array}$ \\
\hline FAGE & & $\begin{array}{l}3.71 \mathrm{e}-09^{* * *} \\
(1.40 \mathrm{e}-09)\end{array}$ \\
\hline SGROWTH & & $\begin{array}{l}-0.0255 \\
(0.0414)\end{array}$ \\
\hline Constant & & $\begin{array}{l}-7.561^{* * *} \\
(1.495)\end{array}$ \\
\hline Pseudo R2 & & 0.13 \\
\hline Observations & & 440 \\
\hline
\end{tabular}

Notes: AUBRN $=$ Big 4 auditors (KPMG, Price Waterhouse Coopers, Ernst \& Young and Deloitte). ACSIZ $=$ AC size, $\mathrm{ACIDP}=\mathrm{AC}$ independence, $\mathrm{ACMET}=\mathrm{AC}$ meetings $\mathrm{ACFAEX}=\mathrm{AC}$ financial expertise, $\mathrm{ACLEX}=\mathrm{AC}$ legal expert, $\mathrm{FACME}=$ female $\mathrm{AC}$ member, $\mathrm{ACSOW}=\mathrm{AC}$ stock ownership, $\mathrm{ACTNR}=\mathrm{AC}$ tenure, $\mathrm{ACCHR}=\mathrm{AC}$ chair independence, $\mathrm{BID}=$ board independence, $\mathrm{BFEX}=$ board expertise, $\mathrm{FSIZ}=$ firm size LEVR = leverage, FAGE $=$ firm age, $\mathrm{SGROWTH}=$ sales growth, Robust standard errors in parentheses ${ }^{* * *} \mathrm{p}<0.01,{ }^{* *} \mathrm{p}<0.05,{ }^{*} \mathrm{p}<0.1$. 
IJMS 25 (2), 39-70 (2018)

\section{Alternative Estimation Using Lagged Values of the Predictor Variables}

This section presents alternative estimation for the model using lagged values of the predictor variables. This is because endogeneity is a common problem associated to accounting research; it arises because of simultaneous consequences, explanatory variables and omitted variables (Larcker \& Rusticus, 2010). It is contended that the link between the internal governance instruments and external auditing could be endogenous, where the strength of internal governance devices might lead to fewer or a prominent need for extensive external auditing; on the contrary, higher quality audits might lead to falling (or rising) other forms of internal governance devices (Hay, Knechel, \& Ling, 2008). However, this study re-estimated the main model using the lagged values of the predictor variables to control this endogeneity problem or reverse causality problem (AlQadasi \& Abidin, 2018; Alves, 2014). Table 7 shows the results of the reestimated model using the lagged values of the predictor variables. Overall, the signs and the coefficients of the main model are similar to those of the sensitivity checks. Thus, it is established that our findings are insensitive to endogeneity problem.

Table 7

Pool Results of the Alternative Estimation for the Model using Lagged Values of the Predictor Variables

\begin{tabular}{lcc}
\hline & & $(1)$ \\
\hline VARIABLES & & $\begin{array}{c}\text { Lagged Values Independent } \\
\text { variables }\end{array}$ \\
& & -0.0101 \\
ACSIZ & $\mathrm{H}_{1}(+)$ & $(0.149)$ \\
& & $2.605^{* *}$ \\
ACIDP & $\mathrm{H}_{2}(+)$ & $(1.134)$ \\
& & $-0.392^{*}$ \\
ACMET & $\mathrm{H}_{3}(+)$ & $(0.206)$ \\
& & $3.081^{* *}$ \\
ACFAEX & $\mathrm{H}_{4}(+)$ & $(0.834)$ \\
& & 0.926 \\
ACLEX & $\mathrm{H}_{5}(+)$ & $(1.216)$ \\
& & $0.788^{* * *}$ \\
FACME & $\mathrm{H}_{6}(+)$ & $(0.232)$ \\
& & $3.35 \mathrm{e}-09^{* *}$ \\
ACSOW & $\mathrm{H}_{7}(+)$ & $(1.50 \mathrm{e}-09)$ \\
\hline & &
\end{tabular}


IJMS 25 (2), 39-70 (2018)

\begin{tabular}{lcc}
\hline & \multicolumn{2}{c}{$(1)$} \\
\hline VARIABLES & $\begin{array}{c}\text { Lagged Values Independent } \\
\text { variables }\end{array}$ \\
\hline ACTNR & $\mathrm{H}_{8}(+)$ & $\left(0.179^{* *}\right.$ \\
& & $-0.609^{*}$ \\
ACCHR & $\mathrm{H}_{9}(+)$ & $(0.353)$ \\
& & $1.834^{*}$ \\
BID & $(0.976)$ \\
& 0.260 \\
BFEX & $(0.709)$ \\
& 0.00969 \\
FSIZ & $(0.0756)$ \\
LEVR & -2.262 \\
& $(6.182)$ \\
FAGE & $0.0189^{* *}$ \\
SGROWTH & $(0.00826)$ \\
Constant & 0.0315 \\
Pseudo R2 & $(0.0411)$ \\
Observations & -1.079 \\
\hline Notes: AUBRN & $(1.698)$ \\
\hline
\end{tabular}

Notes: AUBRN = Big 4 auditors (KPMG, Price Waterhouse Coopers, Ernst \& Young and Deloitte). ACSIZ $=$ AC size, $\mathrm{ACIDP}=\mathrm{AC}$ independence, $\mathrm{ACMET}=\mathrm{AC}$ meetings ACFAEX $=$ AC financial expertise,$A C L E X=A C$ legal expert, $\mathrm{FACME}=$ female $\mathrm{AC}$ member, $\mathrm{ACSOW}=\mathrm{AC}$ stock ownership, $\mathrm{ACTNR}=\mathrm{AC}$ tenure, $\mathrm{ACCHR}=\mathrm{AC}$ chair independence, $\mathrm{BID}=$ board independence, $\mathrm{BFEX}=$ board expertise, FSIZ = firm size LEVR = leverage, FAGE = firm age, SGROWTH = sales growth, Robust standard errors in parentheses ${ }^{* * *} \mathrm{p}<0.01,{ }^{* *} \mathrm{p}<0.05,{ }^{*} \mathrm{p}<0.1$.

\section{Conclusion}

This paper examined the effect of audit committee attributes on auditor brand name. The results revealed that audit committee attributes enhances audit quality by increasing the likelihood of engaging Big 4 auditors for greater audit assurance. Consistent with complementary hypothesis, the findings show that audit committee attributes are positively related to Big 4 auditors. The findings also support the substitutional hypothesis perspectives by revealing an inverse relationship between audit committee meeting, audit committee tenure, audit committee chair and Big 4 auditors. Our inferences are in line with both the agency theory and institutional theory. The findings are conclusive for these audit committee attributes that have been examined only to a limited extent in prior literature regarding their association with Big 4 auditors. Our findings offer an initial insight on 
the effect of audit committee legal expert and audit committee stock ownership on Big 4 auditors. Thus, the findings inform of the existing and prospective shareholders who are the direct users of financial reports. This study can also help policy-makers and regulators by enabling them to better recognize the importance of these distinctive audit committee attributes in enhancing audits quality, which is one of the most vital elements in improving financial reporting quality.

\section{References}

Abbott, L. J., Parker, S., \& Peters, G. F. (2004). Audit committee characteristics and restatements. Auditing: A Journal of Practice E Theory, 23(1), 69-87.

Abbott, L. J., Parker, S., Peters, G. F., \& Raghunandan, K. (2003). The association between audit committee characteristics and the financial reporting process. Auditing: A Journal of Practice $\mathcal{E}$ Theory, 22(2), 17-32. https://doi.org/10.2308/aud.2003.22.2.17

Abernathy, J. L., Beyer, B., Masli, A., \& Stefaniak, C. (2014). The association between characteristics of audit committee accounting experts, audit committee chairs, and fi nancial reporting timeliness. Advances in Accounting, incorporating Advances in International Accounting, 30(2), 283-297.

Adam, S. I., \& Bala, H. (2015). Ownership structure and audit quality of Nigerian deposit money banks. Journal of Social and Management Science, 2(3), 54-65. Retrieved from file://C:/Users/ HUSSAINI/Downloads/Adam \& Hussaini 2015 (2).pdf

Akhalumeh, P., Agweda, F., \& Ogunkuade, Z. (2017). Corporate characteristics and audit quality: Evidence from quoted firms in Nigeria. Journal of Scientific Research and Studies, 4(3), 59-66.

Aldamen, H., Hollindale, J., \& Ziegelmayer, J. L. (2016). Female audit committee members and their influence on audit fees. Accounting and Finance, 56(1), 1-33.

AlQadasi, A., \& Abidin, S. (2018). The effectiveness of internal corporate governance and audit quality: The role of ownership concentration - Malaysian evidence. Corporate Governance: The International Journal of Business in Society, 18(2), 233-253. https:// doi.org/10.1108/CG-02-2017-0043

Alves, S. (2013). The impact of audit committee existence and external audit on earnings management Evidence from Portugal. Journal of Financial Reporting \& Accounting, 11(2), 143-165. https://doi. org/10.1108/JFRA-04-2012-0018 
Alves, S. (2014). The effect of board independence on the earnings quality: Evidence from Portuguese listed companies. Australasian Accounting, Business and Finance Journal, 8(3), 2343. https://doi.org/10.14453/aabfj.v8i3.3.

Badolato, P., \& Donelson, D.C., Ege, M. (2014). Audit committee financial expertise and earnings management. Journal of Accounting and Economics, 58(2-3), 208-230.

Bala, H., Amran, N. A., \& Shaari, H. (2018). Auditor brand name and financial reporting fraud of listed companies in Nigeria. Akademia Baru. Journal of Advanced Research in Business and Management Studies, 11(1), 84-94.

Bala, H., \& Kumai, B. (2015). Audit committee characteristics and earnings quality of listed food and beverages firms in Nigeria. International Journal of Accounting, Auditing and Taxation, 2(8), 216-227.

Ball, R., Kothari, S. P., Robin, A., \& Pope, P. (2000). The effect of international institutional factors on properties of accounting earnings by the effect of international institutional factors on properties of accounting income. Journal of Accounting and Economics, 29, 1-51.

Barth, M. E., Landsman, W. R., Lang, M., \& Williams, C. (2012). Are IFRS-based and US GAAP-based accounting amounts comparable. Journal of Accounting and Economics, 54(1), 68-93. https://doi.org/10.1016/j.jacceco.2012.03.001

Baxter, P., \& Cotter, J. (2009). Audit committees and earnings quality. Accounting \& Finance, 49(2), 267-290. https://doi.org/10.1111/ j.1467-629X.2008.00290.x

Beasley, M. S. (1996). An empirical analysis of the relation between the board of director composition and financial statement fraud. The Accounting Review, 71(4), 443-465.

Bronson, S. N., Carcello, J. V., Hollingsworth, C. W., \& Neal, T. L. (2009). Are fully independent audit committees really necessary? Journal of Accounting and Public Policy, 28(4), 265280. https://doi.org/10.1016/j.jaccpubpol.2009.06.001

Bruynseels, L., \& Cardinaels, E. (2014). The audit committee: Management watchdog or personal friend of the CEO? The Accounting Review, 89(1), 113-145.

Bushman, R. M., \&Smith, A. J. (2001). Financial accounting information and corporate governance. Journal of Accounting and Economics 32(1-3), 237-333.

Carcello, J. V., Hermanson, D. R., Neal, T. L., \& Riley. (2002). Board characteristics and audit fees. Contemporary Accounting Research, 19(3), 365-384. 
Carcello, J. V., \& Neal, T. L. (2003). Audit committee independece and disclosure: Choice for financially distressed firms. Corporate Governance, 11(4), 289-299.

Chan, A., Liu, G., \& Sun, J. (2013). Independent audit committee members' board tenure and audit fees. Accounting \& Finance, 53(4), 1129-1147

Chen, K. eny., \& Zhou, J. (2007). Audit committee, board characteristics, and auditor switch decisions by Andersen's Clients. Contemporary Accounting Research, 24(4), 1085-1117. https://doi.org/10.1506/car.24.4.2

Choi, J.H., \& Wong, T.J. (2003). Audit marketts and legal environments: An international investigation. Working Paper, (September). http://dx.doi.org/10.2139/ssrn.337840

Cohen, J., Krishnamoorthy, G., \& Wright, A. M. (2002). Corporate governance and the audit process. Contemporary Accounting Research, 19(4), 573-594.

Cohen, J. R., Hoitash, U., Krishnamoorthy, G., \& Wright, A. M. (2014). The effect of audit committee industry expertise on monitoring the financial reporting process. Accounting Review, 89(1), 243273.

Cohen, J. R., Krishnamoorthy, G., \& Wright, A. M. (2008). Form versus substance: The implications for auditing practice and research of alternative perspectives on corporate governance. Auditing, 27(2), 181-198. https://doi.org/10.2308/aud.2008.27.2.181

Davis, G. F., \& Useem, M. (2002). Top management, company directors, and corporate control. A. Pettigrew, H. Thomas, R. Whittington, (Eds.) Handbook of Strategy and Management. Sage, London, UK, 233, 259.

DeAngelo, L. E. (1981). Auditor size and audit quality. Journal of Accounting and Economics, 3(3), 183-199. https://doi. org/10.1016/0165-4101(81)90002-1

Defond, M. L., \& Jiambalvo, J. (1991). Incidence and circumstances of accounting errors. The Accounting Review, 3(66), 643-655.

DeFond, M., \& Zhang, J. (2014). A review of archival auditing research. Journal of Accounting and Economics, 58(2-3), 275-326.

Dezoort, F. T. (1997). An Investigation of audit committees' oversight responsibilities. Abacus, 33(2), 208-227.

Dhaliwal, D., Naiker, V., \& Navissi, F. (2010). The association between accruals quality and the characteristics of accounting experts and mix of expertise on audit committees. Contemporary Accounting Research, 27(3), 787-827. 
Ejeagbasi, G. E., Nweze, A., Ezeh, E., \& Nze, D. (2015). Corporate governance and audit quality in Nigeria: Evidence from the banking industry, European Journal of Accounting, Auditing and Finance Research, 5(1), 18-39.

Fama, E. F., \& Jensen, M. C. (1983). Separation of ownership and control separation of ownership and control. Journal of Law and Economics, 26(2), 301-325.

Fischer, E. M., Reuber, A. R., \& Dyke, L. S. (1993). A theoretical overview and extension of research on sex, gender, and entrepreneurship. Journal of Business Venturing, 8(2), 151-168. https://doi.org/10.1016/0883-9026(93)90017-Y

Garba, S., \& Mohamed, M. B. (2018). Ownership structure and bankruptcy: The effect of audit committee size. International Journal of Engineering \& Technology, 7(4.28), 176-181.

Gomes, A. (2000). Going public without governance: Managerial reputation effects. American Finance Association, 55(2), 615-646.

Hair, J. F., Black, W. C., Babin, B. J., \& Anderson, R. E. (2014). Multivariate Data Analysis, (N. Pearson, Ed.) (Seventh). Upper Saddle Rver.

Hamdan, A. M., Mushtaha S. M., Al-Sartawi, A. M. (2013). The audit committee characteristics and earnings quality: Evidence from Jordan. Australasian Accounting, Business and Finance Journal, 7(4), 51-80.

Hay, D., Knechel, W. R., \& Ling, H. (2008). Evidence on the impact of internal control and corporate governance on audit fees. International Journal of Auditing, 12, 9-24.

Hay, D., Knechel, W. R., \& Wong, N. (2006). Audit fees: A meta-analysis of the effect of supply and demand attributes. Contemporary Accounting Research, 23(1), 141-91.

Hermalin \& Michael S., Weisbach, B. E. (1991). The effects of board composition and direct incentives on firm performance. Financial Management, 20(4), 101-112.

Huang, H. W., \& Thiruvadi, S. (2010). Audit committee characteristics and corporate fraud. International Journal of Public Information Systems, 6(1), 71-82.

Huang, J. (2006). An investigation into the determinants of auditor selection and audit fees in China. PhD Thesis, Cardiff University.

Huse, M., \& Solberg, A. G. (2006). Gender-related boardroom dynamics: How Scandinavian women make and can make contributions on corporate boards, 21(2), 113-130.

Ittonen, K., Miettinen, J., Vähämaa, S., \& Miettinen, J. (2010). Does female representation on audit committees affect audit fees? Quarterly Journal of Finance and Accounting, 49(3), 113-139. 
Jensen, M. C. (1993). The modern industrial revolution, exit, and the failure of internal control systems the failure of internal control systems. Journal of Finance, 48(3), 831-880. https://doi. org/10.1111/j.1540-6261.1993.tb04022.x

Jiang, J. X., Wang, I. Y., \& Wang, K. P. (2018). Big N auditors and audit quality: New evidence from quasi-experiments. Accounting Review, (March). Retrieved from http://www.aaajournals.org/ doi/abs/10.2308/accr-52106

Jiraporn, P., Chintrakarn, P., Tong, S., \& Treepongkaruna, S. (2018). Does board independence substitute for external audit quality? Evidence from an exogenous regulatory shock. Australian Journal of Management, 43(1), 27-41.

Kalbers, L. P. \& Fogarty, T. J. (1993). Audit committee effectiveness: An empirical investigation of the contribution of power. Auditing: A Journal of Practice and Theory, 12(1), 24-49.

Kibiya, M. U., Che-Ahmad, A. B., \& Amran, N. A. (2016). Financial reporting quality, does regulatory changes matter? Evidence from Nigeria. Asian Journal of Multidisciplinary Studies, 4(12), 112-118.

Kim, H., Kwak, B., Lim, Y., \& Yu, J. (2017). Audit committee accounting expertise, CEO power, and audit pricing. Asia-Pacific Journal of Accounting and Economics, 24(3-4),

Klapper, L. F., \& Love, I. (2004). Corporate governance, investor protection, and performance in emerging markets. Journal of Corporate Finance, 10(5), 703-728.

Klein, A. (2002). Audit committee, board of director characteristics, and earnings management. Journal of Accounting and Economics, $33,375-400$.

Kouaib, A., \& Jarboui, A. (2017). The mediating effect of REM on the relationship between CEO overconfidence and subsequent firm performance moderated by IFRS adoption: A moderatedmediation analysis. Research in International Business and Finance, 42(December 2017), 338-352.

Krishnan, J., Wen, Y., \& Zhao, W. (2011). Legal expertise on corporate audit committees and financial reporting quality. The Accounting Review, 86(6), 2099-2130.

Lai, K. M., Srinidhi, B., \& Tsui, J. (2017). Board gender diversity, auditor fees and auditor choice. Contemporary Accounting Research, 33(3), 1681-1714.

Larcker, D. F. \& Rusticus, T. O. (2010). On the use of instrumental variables in accounting research. Journal of Accounting and Economics, 49(3), 186-205. 
Lee, H. Y., \& Mande, V. (2005). The relationship of audit committee characteristics with endogenously determined audit and nonaudit fees. Quarterly Journal of Business \& Economics, 44(3/4), 93-112.

Leung, S. C. M., Srinidhi, B., \& Xie, L. (2017). Auditor tenure, information asymmetry and earnings quality. Working Paper, a Department of Accountancy, City University of Hong Kong, Available at SSRN: https://ssrn.com/abstract=2941949, (March), $1-54$

Martınez, M. C. P, Bel-oms, I., \& Olcina-sempere, G. (2016). Corporate governance, female directors and quality of financial information. Business Ethics: A European Review, 1-23. https:// doi.org/10.1111/beer.12123

Nelson, S. P., \& Devi, S. (2013). Audit committee experts and earnings quality. Corporate Governance, 13(4), 335-351. https://doi. org/10.108/CG-02-2011-0009

Qu,C.T.(2018).Board members with style:Theeffect of auditcommittee members and their personal styles on financial reporting choices, 1-28. https://doi.org/10.1177/0148558X17752804

Raghunandan, K., Read, W. J., \& Rama, D. V. (2001). Audit committee composition, "gray directors," and interaction with internal auditing. Accounting Horizons, 15(2), 105-118.

Saleh, N. M., Iskandar, T. M., \& Rahmat, M. M. (2007). Audit committee characteristics and earnings management: Evidence from Malaysia. Asian Review of Accounting, 15(2), 147-163. https:// doi.org/10.1108/ARA-04-2012-0017

Sani, A. A., Latif, R. A., \& Al-dhamari, R. A. (2018). Can big4 auditors mitigate the real earnings management? Evidence from Nigerian listed firms. Asian Journal of Economics, Business and Accounting, 8(2), 1-10

Sharma, V., Naiker, V., \& Lee, B. (2009). Determinants of audit committee meeting frequency: Evidence from a voluntary governance system. Accounting Horizons, 23(3), 245-263. https:// doi.org/10.2308/acch.2009.23.3.245

Sulaiman, N. A. (2017). Oversight of audit quality in the UK: Insights into audit committee conduct. Meditari Accountancy Research, 1-7. https://doi.org/10.1108/MEDAR-02-2014-0029

Sultana, N. (2015). Audit committee characteristics and accounting conservatism. International Journal of Auditing, 19(2), 88-102.

Sultana, N., \& Mitchell, J. L W., \& Zahn, V. (2013). Earnings conservatism and audit committee financial expertise. Accounting and Finance, 55(1), 279-310. 
IJMS 25 (2), 39-70 (2018)

Thiruvadi, S., \& Huang, H.-W. (2011). Audit committee gender differences and earnings management. Gender in Management: An International Journal, 26(7), 483-498.

Vafeas, N. (2003). Length of board tenure and outside director independence. Journal of Business Finance and Accounting, 30(78), 1043-1064.

Vafeas, N. (2005). Audit committees, boards, and the quality of reported earnings. Contemporary Accounting Research, 22(4), 1093-1122.

Xie, B., Davidson, W. N., \& Dadalt, P. J. (2003). Earnings management and corporate governance: The role of the board and the audit committee. Journal of Corporate Finance, 9(3), 295-316.

Yang, J. S., \& Krishnan, J. (2005). Audit committees and quarterly earnings management. International Journal of Auditing, 9, 201219.

Yermack, D. (2004). Remuneration, retention, and reputation incentives for outside directors. Journal of Finance, 59(5), 22812308.

Zaman, M., Hudaib, M., \& Haniffa, R. (2011). Corporate governance quality, audit fees and non-audit services fees. Journal of Business Finance and Accounting, 38(1-2), 165-197.

Zhang, Y., Zhou, J., \& Zhou, N. (2007). Audit committee quality, auditor independence, and internal control weaknesses. Journal of Accounting and Public Policy, 26(3), 300-327. 